\title{
Taek-Gwang Lee
}

\section{The Politics of Realism}

\section{Lukács and Reflection Theory}

\begin{abstract}
This essay claims that the rejection of Lukács's realism is quite problematic, in the sense that his opponents such as Adorno and Althusser symbolically used the name of Lukács and perpetuated the suspicion of Lukács's compromise with Stalinism. The essay argues that Lukács's model of reflection is not couched in Stalin's socialist realism, a theory that assumes the transparency between aesthetic forms and reality, but rather raises the essential problems of the condition of writers in capitalist society. Lukács's realism aims at providing a practical strategy to overcome cultural reification, focusing on the mediation between an author and his material condition. An investigation of Lukács's realism reveals that Lukács's way of understanding realism arises from his emphasis on objectivity rather than subjective reflection such as Kantian philosophy. The essay claims that this is the kernel of Lukácsean reflection theory signified by an aesthetic of realism definitively opposed to Stalin's socialist realism. From this perspective, the essay takes Althusserian Marxism as the occasion to stage a wide consideration of anti-realism. I propose to elucidate the implicit assumptions behind the decline of Lukács's realism, and the reification of cultural fields that gradually came to dominate Western literary apparatuses.
\end{abstract}

\section{Introduction}

Lukács's defence of realism as a literary mode was one of the most controversial features of his aesthetics in the sense that it precipitated the conflict with other Marxist theorists of his time. ${ }^{1}$ Today, Lukács's defence of realism is often misunderstood as an obsolete edifice after the advent of Western Marxism and Althusserian Marxism. In spite of intermittent debates about contentious aspects of his politics, there are few theorists who have produced a proper evaluation of his aesthetics of realism. It is

1. For more details of the debates between them, see Ernst Bloch and others, Aesthetics and Politics, trans. Rodney Livingstone (London: Verso, 1980).

The AnaChronisT 10 (2004): 61-79 ISSN 1219-2589 
my claim that the theoretical rejection of Lukács's realism is quite problematic, in the sense that his opponents such as Adorno and Althusser symbolically used the name of Lukács and perpetuated the suspicion of Lukács's compromise with Stalinism.

I contend that Lukács's model of reflection is not couched in Stalin's socialist realism, a theory that assumes the transparency between aesthetic forms and reality, but rather raises the essential problems of the condition of revolutionary writers in capitalist society. In this sense, Lukács's realism aims at providing a practical strategy to overcome cultural reification, focusing on the mediation between an author and his material condition. An investigation of Lukács's realism reveals that Lukács's way of understanding realism arises from his emphasis on objectivity rather than subjective reflection, as in Kantian philosophy. ${ }^{2}$

From this perspective, Lukács regards artistic form as "self-containment" in which the totality of the form is more intensively structured than material reality. That is to say, the Lukácsean concept of reflection is not the Kantian correspondence between consciousness and reality, but rather reflection in proper proportion as in a geographical map. This is the kernel of Lukácsean reflection theory, signified by an aesthetic of realism definitively opposed to Stalin's socialist realism. In this respect, Lukács's formulation of realism is a method of mapping out the capitalist social reality beyond fragmentation and reification.

\section{Questions for Lukács's Reflection Theory}

Despite the prejudice that his argument is a mere reflection theory, what Lukács's realism proposes is quite equivocal. At first sight, Lukács's realism seems to suggest a better method to copy reality, yet, paradoxically, his realism implies another meaning at the level of the practical message. As Galin Tihanov argues, Lukács's understanding of realism lies in the way in which he conceptualises method as the expression of Weltanschauung. ${ }^{3}$ There is no doubt that Lukács's formulation of method is partly influenced by the neo-Kantian conceptualisation of the relationship

2. For Lukács's own criticism of Kantian reflection, see Georg Lukács, History and Class Consciousness: Studies in Marxist Dialectics, trans. Rodney Livingstone (Cambridge, MA: The MIT Press, 1999), p. 200.

3. Galin Tihanov, The Master and the Slave: Lukács, Bakhtin, and the Ideas of Their Time (Oxford: Clarendon Press, 2000), p. 108. 
between an individual artwork and Weltanschauung. ${ }^{4}$ Lukács confesses that Georg Simmel, a philosopher of Lebensphilosophie, gave him the idea of the social character of art. Yet Lukács also maintains that Simmel's influence was nothing less than "a basis for the discussion of literature that went well beyond Simmel's own." 5 For this reason, it seems to me that it is not the transcendental category of Weltanschauung in neo-Kantian aesthetic that is crucial to Lukács's formulation of realism, but rather the subject-object dialectic, responding to both Hegelianism and neo-Kantianism. According to Tihanov, for the early Lukács, who attempted to reformulate the neoKantian idea of aesthetics, "embracing Hegel for the purpose of establishing a systematic aesthetics involves a compromise between historical and a priori category."6

In other words, Lukács endorses the Hegelian category of mediation to substantiate the neo-Kantian conception, adapting the teleological view of totality. In this way, Lukács's idea of realism is inseparable from his early philosophical presupposition of form, which was developed in Heidelberg Aesthetics (1916-1918).7 Lukács's doctrine of realism contains the tension between "the Hegelian postulate of the unity of content and form and the neo-Kantian prejudice that only form can upgrade content to essentiality." 8 This is the very principle whereby Lukács regards realism as "a perennial trend in literature ... and a specific, historically determined mode of literary production."9 For Lukács, Weltanschauung is not a priori about artistic creation,

4. As a result of the decline of early neo-Kantianism in 1910, Cassirer and Lask reformulated neo-Kantian ideas in bringing about a convergence with Lebensphilosophie and phenomenology. For a more detailed discussion about this, see Craig Brandist, The Bakhtin Circle: Philosophy, Culture and Politics (London: Pluto, 2002), pp. 16-21.

5. Georg Lukács, Record of a Life: An Autobiographical Sketch, trans. Rodney Livingstone (London: Verso, 1983), pp. 37. However, it is undeniable that the influence of neo-Kantianism is still evident throughout Lukács's whole works. Most importantly, Lukács retains the neoKantian idea of timeless form and modifies it, so that the form of a great realistic artwork is the eternal achievement of human progress.

6. Tihanov, p. 42.

7. According to Tihanov, in Heidelberg Aesthetics, "Lukács presents a more elaborate, if not completely enthusiastic, case for a Hegelian understanding of culture as a possible alternative to Kantianism" (Tihanov, p. 29).

8. Tihanov, p. 42.

9. Tihanov, p. 108. In this way, Lukács's realism has to be subsumed into his later study of Marxist ontology. Explaining the task of Marxist ontology, Lukács argues that "its object was the reality existing. And its task is to investigate the existing and trace it back to its being, and thus to discover the various gradations and connections contained within it." See Georg 
but rather the mode of narrative produced by the mediation between an author and his circumstance. ${ }^{10}$ This is the reason why, as Tihanov acknowledges, "Lukács's category of method seems more plausible and seamlessly attachable to his discussions of particular schools and movements."11 That is to say, Lukács's conception of method, pertaining to the category of Weltanschauung can be properly applied for the periodisation of aesthetic ideologies. ${ }^{12}$

From this perspective, Lukács attempts to draw a distinction between the description of naturalism and the narration of realism. It should be noted that Lukács considers naturalism as "modern realism," the mode of realism without mediation between subject and object. Lukács's scathing criticism of the descriptive method in modern realism explicitly challenges the view that such a technique adequately mirrors the inhumanity of capitalism. Lukács does not admit the position that defends a descriptive method as more realistic, but rather reproaches the writers who employ description to dilute the essential capitalist reality. Along with this criticism, Lukács deplores "modern realism" for making the novel lose "its capacity to depict the dynamics of life, and thus its representation of capitalist reality is inadequate, diluted and constrained."13 For Lukács, "modern realism" designates naturalism and, in Jameson's terms, the coded language of socialist realism. In addition, Lukács himself explicitly defined Stalin's socialist realism as socialist naturalism. ${ }^{14}$ Lukács also criticised the way in which Stalin's socialist realism simply combines political dogmatism with factum brutum without mediation; it represents a configuration of objectivity that is nothing less than inverse subjectivity: Stalinist dogmatism as naturalism.

Lukács, Conversations with Lukács, trans. David Fernbach (London: The Merlin Press, 1974), p. 17.

10. This idea is even found in Lukács's non-Marxist criticism of Kantian aesthetics, when Simmel and Weber fully influenced him. At that time, Lukács already criticised the Kantian presupposition of transcendental aesthetic judgement. Lukács says that "my view was that aesthetic judgements did not possess such priority, but that priority belonged with being." See Lukács, Record of a Life, pp. 37-38. In a sense, this is a fundamental idea constituting Lukács's formulation of aesthetics necessarily followed by realism. Lukács still retains such an idea within his formulation of realism, arguing that "reality . . . has an intrinsic order of priority.” See Lukács, Conversations with Lukács, p. 17.

11. Tihanov, p. 107.

12. This is the very point at which Brecht attacks Lukácsean realism.

13. Georg Lukács, "Narrate or Describe?" in Writer and Critic, trans. Arthur Kahn (London: Merlin Press, 1978), p. 147.

14. See "Die Gegenwartsbedeutung des kritischen Realismus," in Essays über Realismus (Neuwied: Luchterhand, 1971), p. 590. 
As Fredric Jameson observes, "the concept of mediation has traditionally been the way in which dialectical philosophy and Marxism itself have formulated their vocation to break out of the specialized compartments of the (bourgeois) disciplines and to make connections among the seemingly disparate phenomena of social life generally." 15 The category of mediation is the way in which we actually grasp the heterogeneous relationships between the individual phenomena, which appear to be part of abstract homogeneity. Accordingly, mediation does not so much presuppose the conceptual antagonistic dichotomy, identity versus identity, but rather the prereified concrete relationship of particularity as such. In short, identity is not fully constituted in mediation. Hegel argues that mediation is "a conscious Being [the mediator], for it is an action which mediates consciousness as such; the content of this action is the extinction of its particular individuality which consciousness is undertaking." 16

A significant philosophical factor in the Hegelian formulation lies in the conceptualisation of the mediator as an "action" resisting "consciousness" in which all difference is sublimated. Needless to say, Hegel believes in the final triumph of consciousness over the action. Even though Marx arguably draws on enlightenment strategies such as "de-mystification," more significantly, he seems to indirectly highlight the concept of mediation as an action in his discussion of Hegel. Obviously focusing on this principle in his explanation of Lukács's theoretical originality, Jameson argues that "the privileged relationship to reality, the privileged mode of knowledge of the world will no longer be a static, contemplative one, will no longer be one of pure reason or abstract thought, but will be the union of thought and action that the Marxists call praxis, will be one of activity conscious of itself." 17

Putting an emphasis on mediation, Lukács distinguished his realism from "mirroring realism." Lukács plainly argues that writers should take the opportunity to reach a higher aesthetic level by means of realism rather than symbolism. In Lukács's view, therefore, symbolism is a mirror in which writers' subjectivity, not external objectivity, reflects itself. Lukács designates this non-aesthetic aspect as "mannerism," in the sense that this reflection comes to produce repetitively a mirror image as it works. It is in this way that the problem of Lukács's realism does not arise

15. Fredric Jameson, The Political Unconscious: Narrative as a Socially Symbolic Act (Ithaca: Cornell University Press, 1981), p. 40.

16. G.W.F. Hegel, Phenomenology of Spirit, trans. A.V. Miller (Oxford: Oxford University Press, 1977), p. 136.

17. Fredric Jameson, Marxism and Form: Twentieth Century Dialectical Theories of Literature (Princeton: Princeton University Press, 1971), p. 188. 
out of his reflection theory, but rather its pedagogical purpose out of providing a user's guide to revolutionary literature.

In spite of the practical aspect of Lukács's realism, the theory of reflection is still the most suspicious element in Lukács's defence of realism. In particular, Adorno insists that Lukács simply considers the formal and stylistic aspects of an artwork to be reactionary decadence. ${ }^{18}$ Adorno's argument is that form is "self-antagonistic and refracted, through which each and every successful work separates itself from the merely existing." 19 In short, Adorno's defence of form presupposes the autonomy of the artwork distinguished from reality - the artwork obtains its autonomous totality by rejecting realism. Adorno's anti-realist aesthetics has influenced both the defenders of Lukács as well as his opponents.

Despite their sympathetic reception of Lukács, for instance, Jameson and Michael Löwy are not interested in his formulation of reflection theory. Their focuses are on the early Lukács of History and Class Consciousness where he explicitly formulates his theory against the Kantian concept of reflection. What offers a philosophical ground for the Lukácsean formulation of realism is that form is a specific spatiality in which the temporality of reality has been fixed. For Lukács, therefore, form is a spatialisation of time in which the logic of content is structured by mediation between author and reality. In Lukács's terms, that is to say, "content" does not so much designate a monadic unity of reality as heterogeneous reality itself - one form does not have one content but many contents. This Lukácsean concept of content is incisively drawn from the way in which Lukács understands reality as the total sum of events.

The issue that Lukács seriously raises in this formulation of realism arises from his disenchantment with Kantian transcendental aesthetics, in which Kant presupposes space and time as a priori epistemological conditions. For Kant, space and time do not belong to experience but rather to the a priori condition of experience, in the sense that every experience is constituted within a specific combination of spatiality and temporality. In this respect, Kant regards time and space as "two sources of knowledge, from which bodies of a priori synthetic knowledge can be

18. See Theodor W. Adorno, "Reconciliation under Duress," in Aesthetics and Politics, trans. Rodney Livingstone (London: Verso, 1980), p. 153. For more details on Adorno's defence of form against Lukács's stress on content, see Theodor W. Adorno, Aesthetic Theory, trans. Robert Hullot-Kentor (Minneapolis: University of Minnesota Press, 1997), p. 142.

19. Adorno, Aesthetic Theory, p. 142. 
derived." ${ }^{20}$ In other words, time and space as the pure form of all intuition make $a$ priori synthetic knowledge possible. However, Lukács refutes this Kantian proposition of time and space as a priori conditions of knowledge. Lukács presumes that time is not a homogenous medium, in the sense that the world is not constituted by a conglomerate of individual things but by a complex of events. ${ }^{21}$ Largely endorsing the Hegelian dialectic, Lukács understands reality as combinations of essence and appearance - crucially for Lukács these categories of essence and appearance are not merely by-products of consciousness but the effects of the outer world. No doubt, this is where Lukács reverses the Kantian idea of representation.

Explicitly distinguishing reality from fact, Lukács defines reality as the changeability everlasting of essence and appearance. From this perspective, the Lukácsean category of totality comes to exist in its own right - "the category of totality ... determines not only the object of knowledge but also the subject." ${ }^{22}$ In other words, the subject of totality means the classes in capitalist society. Therefore, Lukács definitely designates the collective subjectivity of classes when he mentions the dialectical relationship between subject and object.

More controversially, what Lukács apparently rejected in History and Class Consciousness was the very Kantian concept of reflection; Lukács's realism seems to betray his early theoretical principle of non-reflection theory. Lukács criticised the Kantian concept of reflection because in this formulation "we find the theoretical embodiment of the duality of thought and existence, consciousness and reality."23 According to Lukács, Kant strove to solve this duality by logic; yet, "his theory of the synthetic function of consciousness in the creation of the domain of theory could not arrive at any philosophical solution to the question," in the sense that Kant searched for the answer only in the realm of metaphysics. That is to say, there is the fundamental duality inherent in the Kantian formulation that presumes the dichotomy of phenomenon and the thing-in-itself. Lukács was well acquainted with this philosophical dilemma as follows:

It must be clearly understood that every contemplative stance and thus every kind of "pure thought" that must undertake the task of knowing an

20. Immanuel Kant, Critique of Pure Reason, trans. Norman Kemp Smith (London: Macmillan, 1929), p. 80.

21. See Martin Jay, Downcast eyes: The Denigration of Vision in Twentieth-Century French Thought (Berkeley: University of California Press, 1993), p. 196.

22. Georg Lukács, History and Class Consciousness, p. 28.

23. Lukács, History and Class Consciousness, p. 200. 
object outside itself raises the problem of subjectivity and objectivity. The object of thought (as something outside) becomes something alien to the subject. This raises the problem of whether thought corresponds to the object!

Even with a cursory reading, it is clear that Lukács decisively presents the meaning of reflection in this quotation as correspondence, not using the term as in his later conceptualisation of reflection. As Béla Királyfalvi argues, "in Lukács's system the term 'reflection' is a constant reminder of the objectivity of art, but it definitely does not have a passive, mechanical meaning, with implications of copying, photography, or any kind of naturalistic technique." ${ }^{24}$ Seemingly, Lukács preserves his criticism of the Kantian concept of reflection even when he attacks naturalism as "mirror realism," adapting Lenin's reflection theory. Therefore, it must be stressed that Lukács depends on a different terminology in his defence of realism from his early theoretical articulation. Lukács regards Kant's philosophical impasse as an inevitable consequence of the "theory" itself - while he defends the positive feature of Kant's epistemology. In other words, Lukács does want to retain the optimistic factor of Kant's philosophical question as to the relationship of subject and object, while minimising a metaphysical aspect innate in Kant's theory. The solution that Lukács alternatively prepares for Kant's theoretical dead-end is to introduce the concept of totality. Even though many theoretical opponents harshly attack Lukács's concept of totality, few properly present an alternative to the concept, much less an acceptable criticism of it. ${ }^{25}$

\section{Realism against Stalinism}

Despite the constructive aspect of Lukács's aesthetics, it is interesting that most of his defenders even go so far as to regard Lukács's realism as another version of a vulgar reflection theory. The conspiracy of silence around Lukács's reflection theory, I suggest, arises from Lukács's political career and his compromise with "official Marxism." No doubt, this individual history leads to the prejudice that Lukács's defence of realism is nothing less than a by-product of his politics. Even for Jameson, who has consistently endorsed Lukács, it is the uncomfortable truth that Lukács used

24. Béla Királyfalvi, The Aesthetics of György Lukács (Princeton: Princeton University Press, 1975), p. 56.

25. Adapting Benjamin's terminology, for instance, Adorno attempts to substitute the concept of totality for that of constellations. 
a naïve reflection theory to privilege the position of realism over other representational modes. In a rather coy reference to reflection theory, Jameson situates this disturbing aspect of Lukács's realism within the historical condition in which Lukács's theory was constructed. After describing the dichotomy of base and superstructure which is commonly attacked as a vulgar Marxist theory by non-Marxists, Jameson defends this classical Marxist schema in the sense that it can be extended into allegorical interpretation. ${ }^{26}$ In his following discussion, Jameson states that "Lukács's essay on realism may serve as a central example of the way in which the cultural text is taken as an essentially allegorical model of society as a whole." ${ }^{27}$

For Jameson, allegory is a rhetorical strategy produced under conditions where one cannot represent something, but, at the same time, one cannot not represent something. ${ }^{28}$ To put it another way, the represented narrative is essentially allegorical in the sense that form is always less perfect than material reality itself. Jameson's understanding of Lukács comes through an allegorical approach to realism. Jameson suggests the way in which "typification," Lukács's key concept in his conceptualisation of realism, can be grasped as an allegorical method that allows us to read the mode of production in terms of an ultimately determining reality. In short, Jameson depends on allegorical interpretation in order to recuperate Lukács's realism. He then reaches a resolution of criticisms of Lukács's reflection theory by historicising Lukács's work. A direct consequence of this historicisation is the theoretical eclipse of the most political dimension of Lukács's realism.

The hidden impetus behind Lukács's formulation of realism was his own intellectual demand to overcome the subjectivist tendency in History and Class Consciousness. The following quotation from "Preface to the New Edition" elucidates this transition undertaken by Lukács:

My intention, then, was to chart the correct and authentic class consciousness of the proletariat, distinguishing it from "public opinion surveys" (a term not yet in currency) and to confer upon it an indisputably practical objectivity. I was unable, however, to progress beyond the notion of an "imputed" [zugerechnet] class consciousness .... Hence, what I had intended subjectively, and what Lenin had arrived at as the result of an authentic

26. Jameson, The Political Unconscious, pp. 32-33.

27. Jameson, The Political Unconscious, p. 33.

28. For Jameson's own explanation of allegory, see Fredric Jameson, "Marxism and the Historicity of Theory: An Interview with Fredric Jameson,” New Literary History 29 (1998) $353-83$, p. 376. 
Marxist analysis of a practical movement, was transformed in my account into a purely intellectual result and thus into something contemplative. In my presentation it would indeed be a miracle if this "imputed" consciousness could turn into revolutionary praxis. ${ }^{29}$

If we consider that Lukács wrote this "Preface" in 1967, we realise that this statement aims to valorise Lenin's achievement. Lukács drew on Lenin as a symbolic authority in order to attack Stalinism's legitimacy. When interpreting Lukács's words, we become aware that his emphasis was not on Lenin as such but rather on a "practical" objectivity analysed by Lenin. In this sense, what Lukács initially intended in his transformation from "pure class consciousness" to a reflection theory was rooted in his political and philosophical resolution that appears to be in opposition to his early theoretical trajectory. It is not difficult to see that Lukács's way of accepting Lenin's reflection theory is entirely different from the official Marxist model. Michael Löwy argues that Lukács's book on Lenin is "in complete conformity with Leninist orthodoxy but, curiously enough, immediately enters into conflict with the official interpretation of Leninism in the Soviet Union, which is that of Stalin."3o In this respect, the original idea of Lukácsean realism has no relation to Stalinist dialectical materialism. Unlike Stalin's socialist realism, Lukács's model does not presuppose the transparency of reflection between consciousness and the natural law - "thinking" is not merely a by-product of the mechanical causality outside of human consciousness. According to Stalinist dialectical materialism, "thinking" is nothing less than a cognitive function whereby human consciousness simply obtains knowledge of the natural law. ${ }^{31}$ Describing the transitional moment in Lukács, Alex Callinicos states:

It must be stressed, however, that History and Class Consciousness is a transitional work. The last two essays, "Critical Observations on Rosa Luxemburg's Critique of the Russian Revolution," and "Towards a Methodology of the Problem of Organization,” form a unity with Lukács's little book,

29. Lukács, History and Class Consciousness, pp. xviii -xix.

30. Eva L. Corredor, Lukács after Communism: Interviews with Contemporary Intellectuals (Durham, NC: Duke University Press, 1997), p. 18. Around this moment, Lukács's views of Stalinism and the USSR became more radical. For a detailed discussion, see Michael Löwy, "Lukács and Stalinism," in New Left Review, 91 (1975) 25-45.

31. See Oskar Negt, "Marxismus als Legitimationswissenschaft: Zur Genese der stalinstischen Philosophie,” in Nikolai Bucharin/Abram Deborin: Kontroversen über dialektischen und mechanistischen Materialismus (Frankfurt am Main: Suhrkamp, 1974). 
Lenin (1924). Together these texts represent a marked shift away from the messianism of his early Marxism, and an acceptance of Lenin's "revolutionary Realpolitik."32

It seems to me that this gives us a clue as to the reason why Lukács vehemently formulated a reflection theory, which seemed to be sharply contrasted to subjectivism. My contention is that after History and Class Consciousness, when he began strategically following Lenin, Lukács's aesthetic of realism was fundamentally opposed to the pseudo-socialist realism presented by Stalin. In this respect, Lukács's realism can be seen as a form of anti-Stalinist code disguising its political meaning under the veil of aesthetics. From the mid-1930s onwards, Lukács launched critical sallies against the naturalism of writers such as Zola and Flaubert. Interestingly, Jameson indicates that "in Lukács's work, 'naturalism' is a code word for 'socialist realism.' "'33 For Jameson, Lukács's criticism of Zola is a strategy to disguise his attack on "what is publicly impossible to attack as such." 34 In this way, Jameson says that "Zola was not only a writer with certain political positions who might demand to be judged on their basis, or evaluated on their basis, but he was also the inventor of a mode of writing, naturalism, which was current in Lukács's day and which Lukács indeed identified with socialist realism.” In Gelebtes Denken, Lukács himself briefly mentions his Leninist differentiation as "opposed to Stalin's mechanical uniformity." 35 This fragment clearly reveals the complicated political and aesthetic meaning of Lukácsean realism.

Meanwhile, there is a broad consensus amongst Western intellectuals that Lukács's realism is nothing less than an aesthetic collaboration with Stalinism. For example, David Pike attempts to stress the Stalinist aspect of Lukács's realism, arguing that in the period of Soviet exile, 1933-1939, Lukács wittingly supported Stalin's doctrine with his aesthetic writings. Pike claims that "Stalin's remarks at the seventeenth congress were significant for Lukács because he claimed the struggle for objectivity in art, which for him was pre-eminently a question of form, to be part of the battle 'against capitalist residues in the consciousness of the people.' "36 From this

32. Alex Callinicos, Marxism and Philosophy (Oxford: Clarendon Press, 1983), p. 78.

33. Jameson, The Political Unconscious, p. 37.

34. Corredor, p. 78.

35. Lukács, Record of a Life, p. 165.

36. David Pike, Lukács and Brecht (Chapel Hill: The University of North Carolina Press, 1985), p. 144. 
standpoint, Pike regards "Art and Objective Truth" as evidence that Lukács coupled his aesthetic idea to Stalinism.

However, the way in which Pike criticises Lukács's realism is quite problematic. His assertion that Lukács's realism is a by-product of Stalinism does not seriously consider the question as to how a political doctrine imposes on literary criticism. The problem lies in the way in which Pike reductively conflates Lukács's political agenda with his aesthetic idea. Lukács's formulation of realism is more complicated than what Pike describes. As Tom Rockmore acknowledges, "Lukács's early interest in German neo-Kantianism influenced his entire later development, specifically including his aesthetic views." 37 Tihanov also claims that Lukács's doctrine of realism "was shaped in the process of responding not only to Hegel's concept of totality but also to the attempts of Lebensphilosophie to reconcile form and life." 38 In this sense, a judgement that the principle of Lukácsean realism is nothing less than an aesthetic variant of Stalinism cannot be easily delivered.

More problematically, Pike overlooks the fact that Lukács completed the book on Lenin, which shows the essential idea of his realism, in 1924. In this book, Lukács argues that Lenin's assessment of reality is "far more a purely theoretical superiority in accessing the total process." 39 No doubt Lukács's understanding of Lenin's theory anticipates his later principle of realism: the realistic form of an artwork is superior to other aesthetic forms in its ability to access the total process of reality. Even though one can see a similarity between Lukácsean realism and Stalinism, it is difficult to consider it as an essential and fundamental reconciliation.

Rather than Pike's criticism, Rockmore's analysis of the affinity between Lukács's realism and so-called "official Marxism" might be better taken for granted. Rockmore points out an interesting aspect of Lukács's formulation of realism: "the reflection theory of knowledge has no demonstrable source in Marx, the source of Lukács's earlier critique of this view. Hence, in returning to the reflection theory which he had earlier criticised, Lukács now agrees with Marxism, even if necessary against Marx."40 This logical syllogism discloses that Lukács's realism is no more than symptomatic evidence of his alteration of Marx; Lukács's formulation of Marxism is created by his theoretical reinvention emphasising the Hegelian aspect of

37. Tom Rockmore, "Lukács, Marxist Aesthetics, and Truth," in Jahrbuch der internationalen Georg-Lukács-Gesellschaft, 2001 (Bielefeld: Aisthesis, 2001).

38. Tihanov, p. 103.

39. Georg Lukács, Lenin: A Study on the Unity of his Thought, trans. Nicholas Jacobs (London: NLB, 1970), p.42.

40. Rockmore, "Lukács, Marxist Aesthetics, and Truth," pp. 147-8. 
Marx. As Tihanov indicates, "while an uncontested political affiliation was driving him towards a full embrace of Marx, a lasting sense of measure, historical continuity, and the unrestricted sway of reason was propelling him towards an appreciation of Hegel as the philosopher par excellence, whose thought, regardless of all delusions and limitations, posits the true scale and depth of Marxism." 41

However, there is another issue raised by Lukács's modification of Hegel. Analysing Hegel's conceptualisation of the dialectic of labour in The Young Hegel, Lukács argues that

Man becomes human only through work, only through the activity in which the independent laws governing objects become manifest, forcing men to acknowledge them i.e. to extend the organs of their own knowledge, if they would ward off destruction. $4^{2}$

According to Tihanov, this book, The Young Hegel, is Lukács's doctoral dissertation submitted to the Institute of Philosophy of the Soviet Academy of Sciences during Lukács's second stay (1933-45) in Moscow.43 What is at stake here is that Lukács's analysis of Hegel can be easily compatible with the Stalinist doctrine of dialectical materialism. For Stalinism, the process of labour is an objectified system legitimated by natural law. This seems to be easily followed by the notorious confusion between economic mechanism and natural law. Lukács's discussion of Hegel seems to be insensitive to such a dangerous possibility. Not surprisingly, this is where Löwy raises issue with Lukács's political harmonisation with Stalin to solve the dilemma of "either 'reconciling with reality' by accepting the Stalinist Soviet Union or breaking with the communist movement." 44

\section{The Politics of Lukácsean Realism}

For Lukács, there would be no choice except actually existing socialism, in the sense that his philosophical premise was grounded on a fundamental antagonism towards capitalism. This principle of his way of understanding the world system has frequently been considered the result of Lukács's dogmatic "evolutionism." When he

41. Tihanov, p. 248.

42. Georg Lukács, The Young Hegel: Studies in the Relations between Dialectics and Economics, trans. Rodney Livingstone (London: Merlin Press, 1975), p. 327.

43. Tihanov, p. 246.

44. Corredor, p. 19. 
drew on Lenin's reflection theory, Lukács presupposed that the evolution of the artwork necessarily reflects the material conditions of society. Lukács's theory of reflection according to the traditional dualism of base and superstructure remained established until the early 1930s. Criticising the Lukácsean exploration of a modernist work of art, for example, Perry Anderson says that "the basic error of Lukács's optic here was its evolutionism." 45 According to Anderson, evolutionism means that "time ... differs from one epoch to another, but within each epoch all sectors of social reality move in synchrony with each other, such that decline at one level must be reflected in descent at every other." In the same way, Anderson uses evolutionism in his rumination on Lukács's criticism of modernism. It goes without saying that Lukács's understanding of "healthy art and sick art" can be criticised as the result of his evolutionism. This is the main point of Anderson's argument in that Lukács's attack on modernism is anachronistic. Anderson convincingly points out the problem of Lukácsean reflection theory, yet, at the same time, he fails to observe that Lukács's sense of evolution metaphorically alludes to the utopian unity of subject and object in artistic reflections. To quote Lukács:

When we consider mankind's evolution through the ages, art is seen to be one of the most important vehicles for the production and reproduction and for the development and continuity of man's consciousness and sense of identity. Because great and healthy art fixes those moments of our development - otherwise transitory - that point ahead and enhance man's selfconsciousness and are thus lasting and because perfected forms allow the re-experiencing of these moments, great and healthy works of art remain an ever-renewing treasure for mankind. 46

What Lukács argues here implies that perfected forms are indicative of the utopian reconciliation between subject and object in narrative. That is to say, form must be grasped as the incarnation of an author's utopian impulses towards totality. Contrary to Anderson's argument, Callinicos maintains that the most important influence on Lukács, including other Hegelian Marxists such as Antonio Gramsci and Karl Korsch, was "the anti-naturalist revolt at the turn of the nineteenth century." 47 In short, a significant philosophical factor in Lukács was not evolutionist materialism

45. Perry Anderson, "Marshall Berman: Modernity and Revolution," in A Zone of Engagement (London: Verso, 1992), p. 33.

46. Georg Lukács, "Healthy or Sick Art?," in Writer and Critic, trans. Arthur Kahn (London: Merlin Press, 1978), p. 109.

47. Callinicos, p. 71. 
in the sense of naturalism, but anti-empiricist materialism in the sense of Marxism. What Lukács essentially aimed to do throughout his works was nothing less than "the reinterpretation of historical materialism." 48 In a sense, the suspicious aspects of evolutionism are inevitably internalised in Lukács's formulation, insofar as he endorses the orthodox dualism of base and superstructure. However, Lukács's case was not similar to Christopher Caudwell's vulgar dualism, precisely because from the outset Lukács's involvement with Marxism was based on an anti-empiricist materialism.

Lukács does not endorse the "empiricist ideology" but "experience" as such.49 Certainly, the way in which Lukács privileges experience is drawn from Hegel's distinction between empiricism and experience. Regarding experience as "raw sensory material" distinguished from abstract philosophical thinking, Hegel believes that he can refute empiricism. In fact, Hegel's differentiating of experience and the abstract is derived from Kant and Hume, who emphasise the indeterminacy of the relationship between experience and thought. $5^{\circ}$ This discrimination is implicit in the way in which Lukács defends realism in the sense that an author's own experience is more important than his abstract idea. It is in this sense that Lukács considers realism as more aesthetic than naturalism and modernism. That is to say, what Lukács pursues through his arguments about realism is this sensuous material that is independent of abstract thinking in the Hegelian sense.

Lukács inevitably drew on the orthodox concept of base and superstructure, as he did not yet have the appropriate narrative to manifest his idea of realism at that moment. In addition, the theoretical transition of Lukács's realism was definitely witnessed after the mid-1930s. In the face of Stalinism, Lukács launched a disguised criticism of official Marxism through the epistemological category of realism..$^{5^{1}}$ It is in this sense that Lukács's realism must be considered as the aesthetic surface of a

48. Callinicos, p. 72.

49. See Lukács, Conversations with Lukács, pp. 13-14. Lukács claims: "someone is crossing the road. He might be the most obstinate neo-positivist in his epistemology, denying all reality, but he will nevertheless be convinced at the pedestrian crossing that, if he does not remain where he is, he will really be run over by a real car, rather than some kind of mathematical formulation of his existence being run over by the mathematical function of the car, or his idea by the idea of the car."

50. See Michael Inwood, A Hegel Dictionary (Oxford: Blackwell, 1992), p. 96.

51. See Georg Lukács, "Art and Objective Truth," in Writer and Critic, trans. Arthur Kahn (London: Merlin Press, 1978). 
political contention aimed at correcting the Stalinist voluntarism. This is why Lukács precisely stressed objectivity in opposition to subjectivism..$^{2}$

In general, Lukács stresses the philosophical doctrine of realism: first, materiality outside our knowledge determines language. Second, the process of thought reflects the world as reality. Third, appearance hides a more fundamental reality which exists independently of thought. This is the essential philosophical guideline that Lukács observes in his argument for realism. Therefore, Lukács emphasises narration rather than description in the sense that real entities are concealed by their visual appearance. In other words, Lukács's realism is an attempt to make a hidden reality visible. For Lukács, visualisation serves to suppress reality by means of an illusionary inversion in which subjectivity takes the place of objectivity.

In Lukács's sense, realism does not mean an imaginary correspondence, as in naturalism and symbolism, but a "self-containment" that intensively reflects everyday life in "proper proportion." Self-containment is the way in which the form of an artwork reflects social reality, as in the case of synecdoche. Lukács states that "the totality of the work of art is rather intensive." 53 In other words, the form of the artwork is "the circumscribed and self-contained ordering of those factors which objectively are of decisive significance for the portion of life depicted, which determine its existence and motion, its specific quality and its place in the total life process." Lukács's definition of form as self-containment incisively reserves the possibility of the changeability of form in each historical moment - in Lukács's terms, "history is the history of the unceasing overthrow of the objective forms that shape the life of man." 54 From this perspective, a specific artistic form is manifested by each particular historical epoch. Therefore, what Lukács called perfected forms designates a selfcontained form in which the intensive totality of an artwork cognitively maps the social reality in proper proportion.

As we have seen, Lukács's realism was a detour to get the insight of an alternative socialist system in terms of aesthetic epistemology. For Lukács, aesthetics was always the reverse side of politics, so that his criticism of naturalism and modernism largely aimed to suggest the practical aesthetic criterion for socialist movements. In a

52. For more detailed discussion, see Lászlo Illés, "Georg Lukács's Bemühungen um Realismustheorie," in Literaturtheorie und Literaturkritiken der frühsowjetischen Diskussion (Berlin: Weimar, 1999), p. 567. What Illés enumerates in this essay is that Lukács's realism must be understood in the historical context of Russian socialism. According to this argument, Lukács's realism can be regarded as a coded attack on Stalinist subjectivism.

53. Lukács, "Art and Objective Truth," p. 38.

54. Lukács, History and Class Consciousness, p. 186. 
sense, Lukács's realism can be said to be a "symbolic act" to solve contradictions in actually existing socialism. That is to say, Lukács's realism contains more politically significant implications than his opponents expect. Regarding his unflinching fidelity to the teleological aim of socialism, it can be argued that Lukács's theoretical pursuit towards realism in the 1930 s came through the failure of his political career.

In 1928, Lukács drew up the "Blum Theses" for the Second Congress of the Hungarian Communist Party. As Michael Löwy points out, all that lies behind these draft Theses was "an application to Hungary of the right turn of the Comintern," 55 and, at the same time, "both a continuation of the line of the years 1924-7 and an augury of the Popular Front strategy of 1934-8."56 According to Löwy, Lukács's suggestions were too late and too early in the sense that "these Theses were to be the last echo of the right turn, coming as they did at the very beginning of the International's new 'left' turn." ${ }^{7}$ This misfortune led Lukács to confront hostile criticisms and consequently to write his "hypocritical" self-criticism. Lukács acknowledged this in the "New Preface" as follows:

When I heard from a reliable source that Béla Kun was planning to expel me from the Party as a "Liquidator," I gave up the struggle, as I was well aware of Kun's prestige in the International, and I published a "selfcriticism." I was indeed firmly convinced that I was in the right but I knew also - e.g. from the fate that had befallen Karl Korsch - that to be expelled from the Party meant that it would no longer be possible to participate actively in the struggle against Fascism. I wrote my self-criticism as an "entry ticket" to such activity as I neither could nor wished to continue to work in the Hungarian movement in the circumstances. ${ }^{8}$

Regardless of some polemical problems arising from these remarks, Lukács's unconditional capitulation to his inner opponents was the consequence of his own circumstances. As Löwy explains, Lukács saw the situation as an "isolated phenomenon" and "temporary aberration." 59 As a result, we could consider Lukács's Theses to be an incorrect anticipation, in the sense that the new turn, which would provide an opportunity for the Theses, would only come when "it was too late, after Hitler's vic-

55. Löwy, p. 29.

56. Löwy, p. 30.

57. Löwy, p. 29.

58. Lukács, History and Class Consciousness, p. xxx.

59. Löwy, p. 31. 
tory and the establishment of fascism in the heart of Europe."6o This analysis would be incomplete without mentioning another important element manifested in the "Blum Theses." We need to realise that these Theses provide notable evidence for understanding Lukács's theoretical turn from early pure class-consciousness theory into reflection theory. Löwy's analysis is validated by linking Lukács's political nonfulfilment to his reflection theory. As Löwy points out, "the ebbing of the revolutionary tide, and the internal changes in the USSR after 1924" forced Lukács to feel disillusionment: 61

Disoriented by the disappearance of the revolutionary upsurge, Lukács clung on to the only two pieces of "solid" evidence which seemed to him to remain: the USSR and traditional culture. Seeing that the new, transcendent synthesis had failed, he would at least attempt a mediation, a compromise and an alliance between these two different worlds.

For Lukács, this "reconciliation" of bourgeois-democratic culture and the socialist movement may appear to be more realistic than the utopian Messianism that his early hopes presupposed. Lukács confessed that Lenin's intellectual personality, a "philosopher of praxis, a man who passionately transforms theory into practice, a man whose sharp attention is always focused on the nodal points where theory becomes practice, practice becomes theory," forced him to revise the Messianic features of History and Class Consciousness. ${ }^{62}$ According to Lukács, this was the process in which he came closer to reality. From utopian Messianism to "Realpolitik," Lukács attempted to develop a reflection theory derived from Lenin, not in an abstract philosophical sense, but in a practical sense.

After the mid-1930s, Lukács intended to wrest realism from Stalinism. As Johan Vogt indicates, Lukács's harsh criticism of authors such as Hugo and Zola "struck also the panegyrical Soviet novels of the Stalin period." ${ }_{3}$ As has been discussed, in distinguishing Stalinism from Leninism, Lukács emphasised that Lenin's policy was more "realistic" than Stalinism, in the sense that the Leninist method was nothing less than an attempt to present policy changes as "logical consequences and im-

6o. Löwy, p. 32.

61. Löwy, p. 39.

62. Lukács, History and Class Consciousness, p. xxxii.

63. Johan Vogt, "The Harmony of Passions and Reason," in Georg Lukács Festschrift (Neuwied: Luchterhand, 1965), p. 34. 
provements of the previous line.”64 For Lukács, Lenin's method was more suitable than Stalinism for reflecting the discontinuous reality of history. One of the reasons why Lukács emphasised the rupture between Lenin and Stalin was that Stalinism "presented all socialist history as a continuous and correct development." Convincingly, this statement reveals a clue whereby we can approach Lukács's reflection theory without any misleading prejudice. Once Lukács embraced this "discontinuity" of history, he would have had to correct his utopian Messianism which seemed to be the dominant feature of History and Class Consciousness. Lukács confessed to this transition to solve the problem of historical development as follows:

In the twenties, Korsch, Gramsci and I tried in our different ways to come to grips with the problem of social necessity and the mechanistic interpretation of it that was the heritage of the Second International. We inherited this problem, but none of us - not even Gramsci, who was perhaps the best of us - solved it. We all went wrong, and today it would be quite mistaken to try and revive the works of those times as if they were valid now. In the West, there is a tendency to erect them into "classics of heresy," but we have no need for that today.

In these remarks, Lukács's intention appears to be quite obvious. What he wanted to historicise was his early epoch, in which he tried to establish the system of knowledge of necessity in historical process. This aim of his theoretical work led him to pronounce "pure class consciousness" based on utopian Messianism. As Lukács himself confessed, this was where the problematic aspect of his early subjectivism came into being. Lukács did not agree with Western Marxism's emphasis on his early work and the assessment that later Lukács is a digression from early Lukács. While this may have become the fate of Lukács's reception in Western intellectual contexts, it has, to an extent, paradoxically betrayed him.

64. Georg Lukács, “Lukács on his Life and Work," New Left Review, 68 (1971), 49-58, p. 51. In this interview, Lukács says that a complete rupture with Stalinism is necessary, in the sense that Stalinism abandoned Leninist method. 